\title{
In the tracks of the impossible
}

\section{Miguel Ángel Rosales}

Miguel Ángel Rosales is a documentary filmmaker based in Seville, Spain. He has directed three awardedwinning short and medium-length films: La Maroma (2011), Atrapados al Vuelo (2012), and Luz en los Márgenes (2013).

Email: mangelrosalesmateos@gmail.com

ORCID: https://orcid.org/0000-0001-9618-4964

DOI 10.17159/2309-9070/tvl.v.56i1.6270

\section{In the tracks of the impossible}

Arising from experiences of slavery and exile, flamenco was strongly influenced, (re)created, and (re)imagined by black people who lived in southern Spanish cities for over 400 years. Despite consistent and intentional erasure, the fact is that between the fifteenth and nineteenth centuries, there was an important Black presence in the Iberian Peninsula. When I began research for Gurumbé: Canciones de tu Memoria Negra (2016) (Gurumbé: Afro-Andalucian Memories), I set out to reveal this history, to break this silence and expulsion that denies the history and legacy — and the humanity — of Afro-Andalusians. And under the many layers of silencing the memory of Spanish Afrodescendants, I found that Black memory had survived in the body. In flamenco, it created a discourse of resistance in the fact of the oppressors which has transcended time and history. Keywords: flamenco, Andalucia, Black Spain, Gurumbé.

In Silencing the Past (1997), Michel-Rolph Trouillot argues that power has a hand in all the phases that involve the construction of the story of the past: in its sources and their selection, in their classification and organization in the archives, the interpretations by the historians of the era-often including covert censorship-and the final writing of a narrative that goes along the national interests. And it is certainly how the disappearance of Black Spanish people can be traced back to the workings of this whole complex process in the construction of Spain's official history. Acknowledging the intentional disappearance of Black history in Spain, Gurumbé: Canciones de tu Memoria Negra (2016) (Gurumbé: Afro-Andalucian Memories) works to unearth, re-member and celebrate Black Spanish memories through the lens of flamenco. While in centring Black memory in Andalucia, the film confronts Spain's racist history; at its core, Gurumbé is about borders. However, embracing Paul Gilroy's The Black Atlantic: Modernity and Double Consciousness (1993), the documentary resituates flamenco within the transatlantic universe of the African diaspora.

The leading role of music and dance in many social relationships across Andalusia, or the ways in which festivals unfold in particular contexts-such as the Zambomba Christmas festivities in Jerez de la Frontera, which features in Gurumbé-reminds us of Seyla Benhabib's "politics of transfiguration," which "burst[s] open the utopian potential within the old" (Benhabib 13). In "emphasiz[ing] the emergence of qualitatively new needs, social relations and modes of association, which burst open the utopian potential within the old [...] utopia portray modes of friendship, solidarity 
and human happiness" (13). The Black Atlantic mobilizes this emphasis in theorizing the African diaspora's cultural expressions. As Gilroy writes, "It points specifically to the formation of a community of needs and solidarity which is magically made audible in the music itself and palpable in the social relations of its cultural utility and reproduction" (Gilroy 37). These cultural forms are associated with collective enjoyment and a desire to invoke "new modes of friendship, happiness and solidarity" in order to overcome social oppression (38).

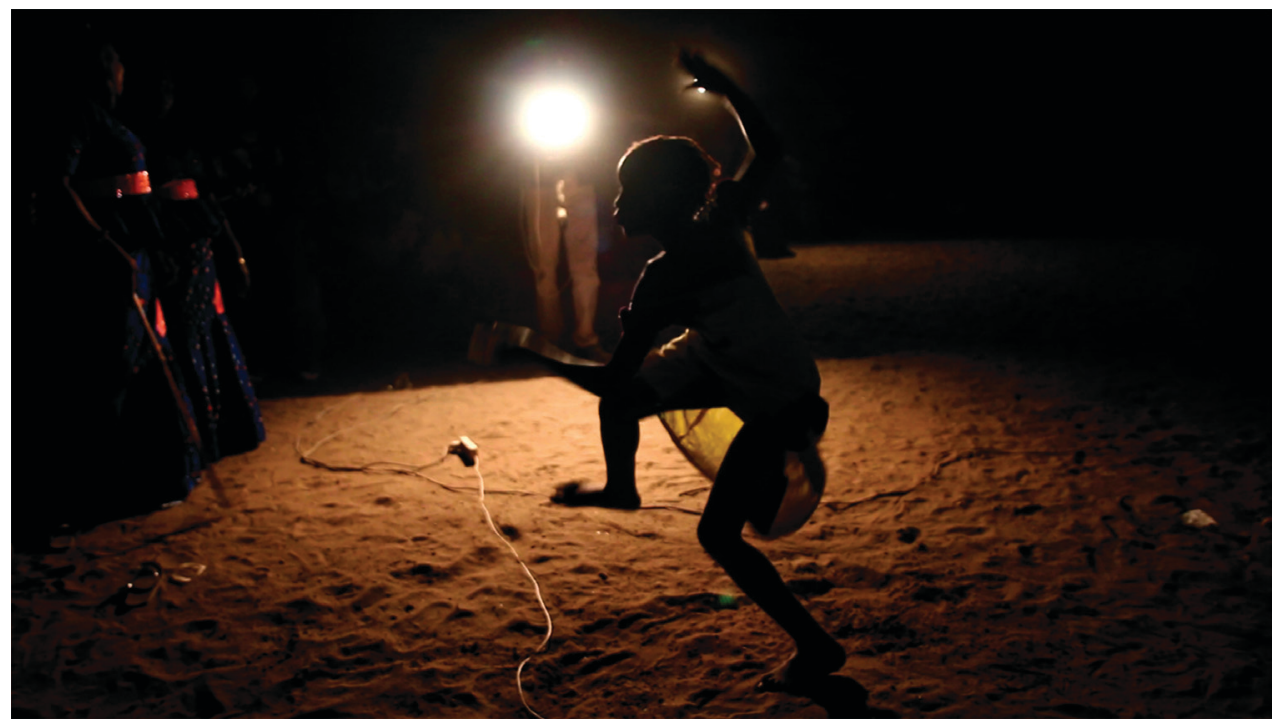

Figure 1: Serer celebration in Joal Faddiouth, Senegal

This is a whole shared expressive world arising from a desire for freedom that creates new ways of relating through celebration (la fiesta) and dance. Gurumbé attempts to explore this in visual language, superimposing the Serer dances from the Joal Fadiouth region of the Senegalese coast, the Zambomba from Jeréz de la Frontera, Andalusia, and the flamenco club in Seville. In these forms of social celebration (hacer la fiesta) there is a play in which the community gives way to individual virtuosity, each participant's unique touch-demanding with it their own place as an individual in a society which denies this - thus forming a deep bond between artist and audience, expressed through the enthusiastic cries (el jaleo) and rhythmic clapping (las palmas) of the spectator-participants, a physical language in which the body expresses itself in all its extension, in a sustained chaos, attempting to appropriate, to make its own, in the present moment, spaces denied in "real life." But also, the extreme, cathartic, tragic, and, at the same time, comic dramatization, the distortion of language into cries, the grimaces-all of this is something that, I argue, flamenco shares with the cultures of the African diaspora. Arising from experiences of slavery 
and exile, flamenco was strongly influenced, (re)created, and (re)imagined by black people who lived in southern Spanish cities for over 400 years. Gurumbé acknowledges, reads, and resituates flamenco as one of the "jewels brought from bondage" that Gilroy (72) speaks of in The Black Atlantic.

\section{Spanish nationalism: a bitter utopia}

The Afro-Andalucian memory referred to in the film's English title confronts the absence of Black Spanish people in Spain's modern history. While references to Black Spaniards can be found within the country's archives and historical records have not been physically destroyed, until recently scholars have largely ignored such resources. Why has such research only recently surfaced?

The National-Catholic version of Spanish history taught us to see the country's origins in the reconquest of Muslim land. This narrative relies on Christianity and pureza de sangre: an untouchable core identity where territory, religion, and race/ culture are united. Literally meaning 'cleanliness of blood,' pureza de sangre played an important role in the modern history of the Iberian Peninsula and its colonies. Originally, referring to those considered to be 'Cristianos viejos' (Old Christians), without recent Muslim or Jewish ancestors, within the context of empire (New Spain and Portuguese India), it came to refer to those without indigenous ancestry from the Americas, Asia, or Africa. In this way, pureza de sangre was foundational in crafting a historical narrative that affirmed a white European identity, allowing Spain to rejoin and participate in a Western history of modernity.

Perhaps the most effective silencing technologies emerged with the great nationalist narratives of the eighteenth- and nineteenth-century European states. Racism rooted itself in the European academies, forging the view of the individual constructed in relation to the 'Other,' who was denied the status of a full human being. Within this framework, African people were denied humanity and thereby their

presence in history. During this period, Spain had 'fallen behind' the rest of Western Europe and was desperately seeking to cleanse itself of its Jewish, Rom, Islamic, and African memories in order to present itself as a respectable white country. In turn, Islam was laundered and Orientalized, the Rom were exoticized and folklorized, and Black Spaniards were actively erased from the national memory.

To replace the Spanish Empire's La leyenda negra (a supposed tendency in historical writing that demonized Spain and the Spanish Empire, its people, and its culture as uniquely cruel and bigoted), a history of Christian, civilized, evangelizing colonialism was written. Spain was able to blot out the story of the African slave trade despite having been one of its greatest promoters. Along with Portugal, it had been the first country to begin importing enslaved people and the last to abolish slavery in its colonies. For several centuries, Spain's cities possessed the largest black and mestizo populations in European history, a population consisting almost entirely of enslaved people. 
In the mid-twentieth century, an era of global decolonization in which communities of color and colonized people demanded and fought for civil rights and independence, Spain languished under Francisco Franco's forty-year dictatorship, a military regime that reiterated the National-Catholic version of Spain's history. And after Franco's death, at the end of the 1970s, the transition to a parliamentary monarchy under the Bourbons, which settled with the same military and political powers which had propped up the dictatorship, brought with it a generalized lack of interest in disseminating a critical vision of history. To this day, this view of Spanish history is still deeply rooted in people's minds: an idealized view of a civilizing, white and Christian Spanish Empire, which ignores the Black presence in Spain, as well as the history of Spanish colonialism.

Today Spanish nationalism suffers from a kind of schizophrenia when it looks to its periphery and confronts its irreducible diversity. It seems that the periphery makes it suffer the "anxiety of incompleteness," identified by Arjun Appadurai in Fear of Small Numbers (2006), defining the tragic distance from a divergent 'other' which does not allow the national self to settle into its utopia of uniformity. Historically, Spain has been constructed in terms of the struggle against its own diversity and mestizaje. In the symbolic realm, one of the main areas of this struggle is the south-Andalusia. In the eyes of Castilian centralism, Andalusia always has been seen as tainted by its contact with Africa and suspected of being 'impure' and not entirely 'civilized.' Its inherent mixture of peoples and cultures has always been troublesome in reinforcing Spanish nationalist imaginaries of whiteness. In response, Black memories have been deeply denied.

Despite consistent and intentional erasure, the fact is that between the fifteenth and nineteenth centuries, there was an important Black presence in the Iberian Peninsula. At times, up to fifteen percent of the population consisted of black people, mostly brought from Africa in bondage or born into slavery in Spain, perhaps the largest black population to have ever existed in European history. Yet, you will not find any records in official history or collective memory because, I would argue, of a construction of history driven by racism - a racism that was both endemic and epistemological. This racism denied enslaved people of their humanity and, with it, the possibility of being part and agents of their own historic time.

When I began the research for the film, I set out to reveal this history, to break this silence and expulsion that denies the history and legacy—and the humanityof Afro-Andalusians. I set out to follow the traces of this memory in audiovisual language. We found, for example, that enslaved black people featured as fixed assets in the commercial transactions of the slave trade, appearing in wills and estate inventories (see Archivo General de Indias). To this day, on the outskirts of Seville, you can still find roads with names relating to the slave trade such as la Cañada de los Negros, which leads from the port of Huelva into the city and runs parallel to la 
Cañada de los Bueyes and other roads whose names refer to cattle. Enslaved people were described as animals, a language that sought to justify their exploitation and use as commodities. Another example of such denials of humanity is the concept of the pieza de ébano (piece of ebony), a measure used to fix the prices and taxes to pay the Crown for the export of each enslaved person. Depending on health, strength, beauty (for women), and age, an enslaved person could be valued as a whole or a fraction. A small child or a person in poor health, for example, could be valued as "half a piece of ebony."

Apart from these sources, we found many other records of Black Spaniards' presence. For instance, writing about her visit to Seville in 1575, Teresa de Jesús, a prominent Spanish mystic, nun, author, and theologian, was reportedly tormented by the Devil in the shape of an "abominable" black boy (de Jesús). Similar representations appeared in the Spanish Siglo de Oro (Golden Age), a period in which art and literature flourished in Spain coinciding with the political rise of the Spanish Habsburg dynasty (between the sixteenth and seventeenth centuries). The stereotypical black characters appearing in many plays during this time, such as Simón Aguado's Entremés de los Negros (1602) and Lope de Vega's El mayor imposible (1647), depicted infantile, undeveloped, incomplete beings whose existence was a transition, under the guardianship of white people, towards another life, where they could find their salvation and humanity (see Fra Molinero). Across the centuries, but particularly prominent in the eighteenth century, travellers' chronicles (i.e. Washington Irving, Jean-Charles Davillier, Richard Ford), stressed the African and mestizo character of Seville when describing the city's atmosphere of lust and sin.

We also found many descriptions of dances, connecting Black Spanish people living in Seville with festivals in the sixteenth and seventeenth centuries in legal documents from the proceedings of the Inquisition, where dances deemed as obscene are described in detail. Notice that, in most cases, the Afro-Andalusian population only gets to break with their invisible condition, to be worthy of recording when their case can be used as an argument to justify their exploitation, or to entrench the prejudices at the base of power.

Once again, why have scholars largely ignored such records? Why has such research only recently surfaced? Among other reasons, a hegemonic official narrative still survives because a critical discourse started to be written very late. It is only after World War II that the first timid studies, by some European academies, began calling into question the Eurocentric history of the West and its relationships with the rest of the world and recognizing the contribution of Africans and their descendants to European economies. However, during this time, Spain was still languishing under the Franco dictatorship and its aftermath. Until the late 1950s, Spain resisted giving up this last African colonial foothold in which, in line with other European powers, it had used extreme violence to subjugate the native peoples and force them into 
plantations. At the end of the 1950s, Spain, under pressure from the United Nations, integrated the colony into the state as a province, thus prolonging, through the patronatos system, semi-slave exploitation and strict racial segregation. This was the case until independence in 1968 after which Equatorial Guinea disappears completely from the history of modern Spain. The supposedly progressive governments of the 1980s and 1990s had no interest in the ancestral African presence in the history of Spain or its recent history of African colonization, of which Equatorial Guinea is a good example (see Nerin). It is only since the 1980s, and in only a few highly specialized areas, that we find studies revealing the slave trading past of the Spanish crown offering a different view of colonial history. Such studies are still marginalized to this day.

\section{Flamenco}

Yet under the many layers silencing the memory of Spanish Afrodescendants, I found that this Black memory had survived in the body. In flamenco, it created a discourse of resistance in the face of the oppressors which has transcended time and history. For instance, religion—represented by the cofradías (religious brotherhoods) of the Andalusian Easter processions and the romerías (religious pilgrimages)—and the expressivity of the music and dance of flamenco have been two significant sites of confrontation and negotiation (Moreno; Ruíz Vergara). In both, the black population played an extremely important role: they were among the founders of the brotherhoods and remained as members for centuries; their contribution to the main elements in flamenco's mix of rhythms and styles was fundamental. The

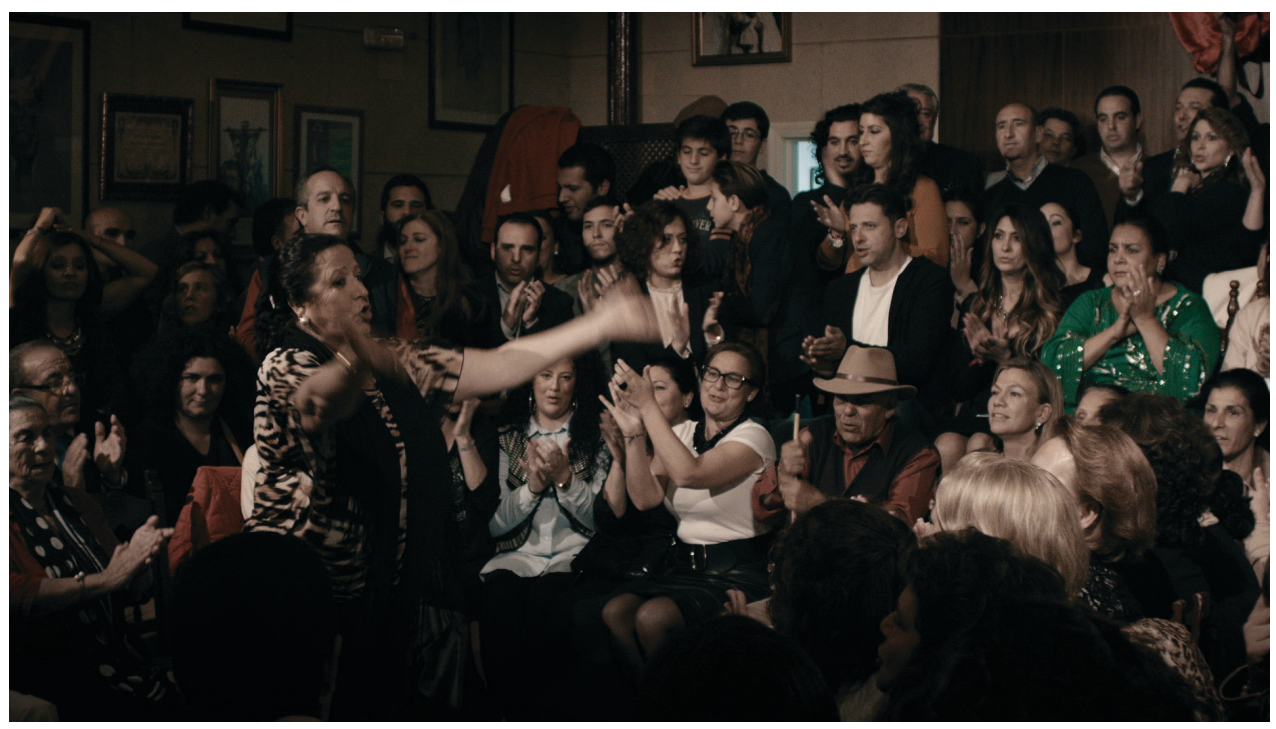

Figure 2: Zambomba, a Flamenco celebration that takes place at Christmas in Jerez de la Frontera 
black populations of the south of Spain and its colonies with their unacknowledged cultural heritage relocated a great part of Andalusian identity in this area of creativity and interchange of people, knowledge, and languages which Antonio García de León calls "the Afro-Andalusian Caribbean". It was through flamenco that, in the documentary film, we could unveil new, visually powerful arguments.

The symbolic domains of ritual and festival are social energy. They create consensus, making them desired domains for centralizing powers. Powers need to contain their fluidity and tie them to its narrative. In this way, power gets to own the bases of the consensus it generates. In the case of flamenco, it also meant cleansing the mestizo genre. Was it a conscious silencing? Or did it happen because it was simply unthinkable at the time that the black population, which had been living in the south of Spain for so many centuries, could have played such a part in the formation of a culture being raised to the status of national heritage? After all, it was unthinkable that the enslaved black people were capable of being actors in history, let alone masters of their own fate or humanity at all for that matter. According to many of the texts circulating at the time which spoke of the African presence, I am inclined to think it was a combination of the two.

There is no space here to sum up in a few lines the process of regulation and institutionalization which, since the birth of flamenco, has attempted to force such a complex phenomenon into standardized features within which the concept of purity is at the core. It would be equally difficult to summarize the processes which have led to flamenco's emergence as one of the most typical representatives of the Spanish national image. As with other hegemonic narratives, there was a tendency to see flamenco through the deeply racist ideas that nineteenth-century European academies and universities were imbued with and which served as intellectual backing for the colonization of Asia and Africa. In Spain, this was mixed with a romantic and folklorized version of the Roma people (a perverse game veering between marginalization/extermination and exotic idealization) who were accredited with the creation and safeguarding of a thousand-year-old tradition of dances and songs which had lost their 'purity' through contact with the modern world. Without casting any doubt over the importance of so many Roma artists in the creation of what is today flamenco, we also cannot be complicit in such a reductionist view.

The first references to flamenco as a style appear in the mid-nineteenth century. Almost as soon as it appeared, it aroused the interest of intellectuals and folklorists who approached it in the scientific spirit of the age. Thus, from very early on, flamenco was seen, from an essentialist standpoint, as a contaminated relic of the deeply-rooted art of a noble people who had succeeded in preserving the tradition over centuries. Its distance from this mythic origin was defined in terms of purity.

One of the first champions and scholars of flamenco was D. Antonio Machado Álvarez, known as "Demófilo." He attempted, in the framework of his Krausist and 
regenerationist beliefs, to rid flamenco of its negative reputation as the music of the rural 'slums' and 'hovels' and to study it in a way which would be of use: para el conocimiento de la naturaleza y evolución del espíritu humano y de las leyes biológicas a que está sometido (in advancing the knowledge of the evolution of the human spirit and the biological laws governing it) (Machado y Álvarez 84).

It was also Demófilo who introduced Darwin's ideas into Spain and created the first folklore societies which approached the "popular" (i.e. lower-class) styles of music from a paternalist, ethnic, and classifying standpoint which has marked the popular view of flamenco for generations, founding what became known as "flamencology." Other flamenco studies went along with the fashionable cultural theories of the times, seeking in Aryan and Indo-European roots evidence of the nobility of a culture and a people. These notions traced the origins of flamenco to India, in a colourful odyssey which was in tune with the romantic, Orientalist spirit of the French and English travellers who gave the leading role to the 'gypsies' (seen as an Orientalized stereotype). All of this is now deeply ingrained in the way most Spaniards and the world see flamenco. And yet, to cite Pedro G. Romero, flamenco has never hidden its origins. If anything, the problem has been the short-sightedness of those who approached it with the aim of studying it and, in doing so, wanted to ennoble it and sanitize its mestizo roots, or see it as a 'gypsy' tradition based on ethnic and racial purity (Romero). I agree more with the idea that flamenco originated around the beginnings of the nineteenth century. Emerging from impoverished urban areas, the music collaged together an extremely broad musical heritage to create a new style. What is more, like many musical genres from the African diaspora, flamenco was created in a repressive and chaotic social context and carved out a transgressive space from within the very heart of a suffocating system of oppression. Numerous historical factors point to the black African base of many of the dances which later gave rise to the flamenco rhythms and the African origins of part of its musical and physical expressiveness (see del Campo and Cáceres).

In nineteenth-century Spain, the working classes were searching for their own music, a style which would contrast with the Court and aristocracy's taste for French and Italian fashions. This was the period in which the new genre took shape, in the hands of great artists who gathered together an immense range of musical and dance heritage, and to which an African contribution was hugely important. Flamenco was created to satisfy the demand of this new audience, primarily working-class mestizo urban dwellers, clustered in the new economic centres-factories, mines, and ports.

Thus, there was a whole musical tradition continually changing shape in each period to give new meanings to texts, take them apart, create new forms, push them to the limits of their expressivity, and incorporate new elements. All of this turned the tablao (flamenco club), the fiesta (popular celebration), and other places devoted to the art into theatres of freedom where bourgeois conventions were overturned, whether 
aesthetic, social, or in the realm of gender roles. In the tablao and the fiesta, a space was opened up which physically defied the prevailing order where workers' bodies could express themselves freely, breaking social norms. Due to its creation of new forms on the basis of an already existing tradition, its transgressive, mestizaje practice, we can say that flamenco has been a modern type of music from its birth, although in direct opposition to the prevailing colonial, globalizing version of modernity.

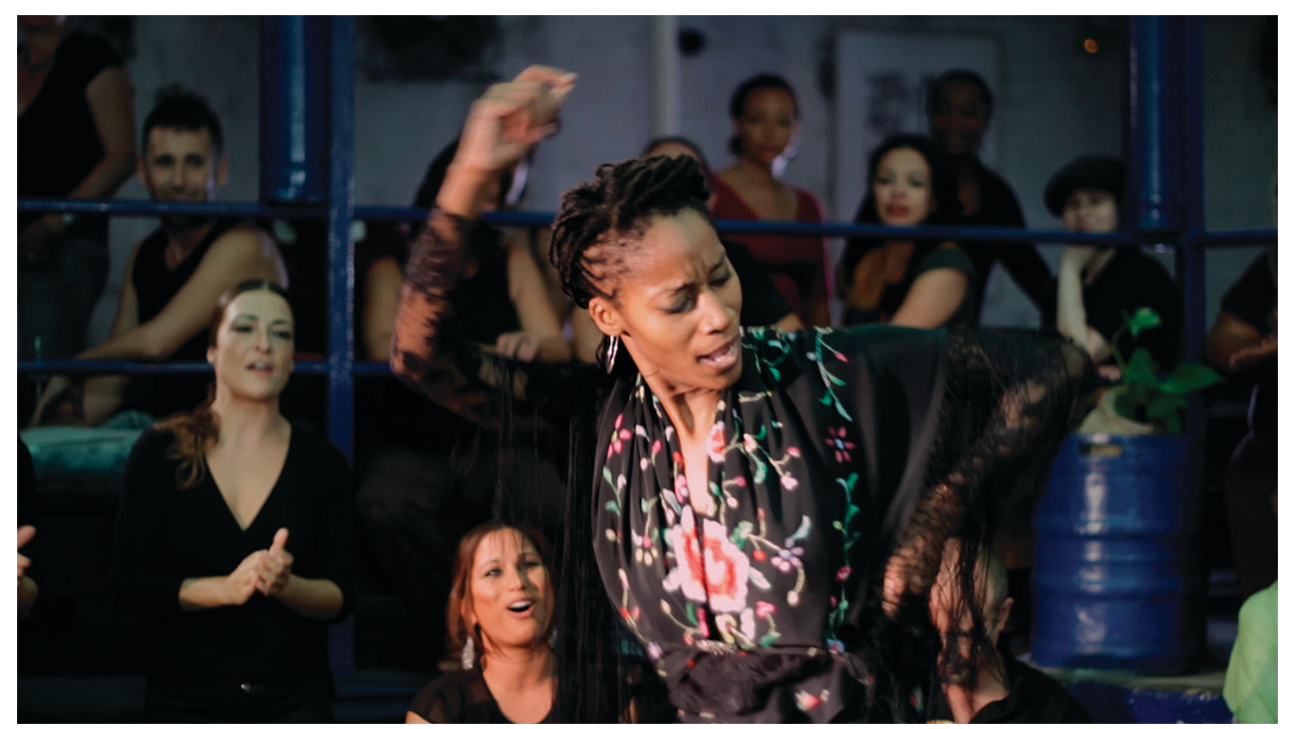

Figure 3: Flamenco dancer, Yinka Esi Graves, performing in Gurumbé: Canciones de tu Memoria Negra

\section{Gurumbé}

Gurumbé is a highly popular dance which appears in print for the first time in " $\mathrm{La}$ Negrina," composed by the early sixteenth-century Spanish musician Mateo Flecha. This piece, written to be performed at Christmas, incorporated the speech of Black Spanish people in words such as Gurumbé, Sansabeya, alangandanga, bonasa, etc., and used the combined two and three rhythms typical of African music. In the composition Flecha brought together songs and dances performed by Black Spaniards in the fifteenth century in the streets of Seville and other southern cities. But what most interests us here is that the morphemes Guru and 'mbe can still be found today in words relating to many musical forms from West Africa and the African diaspora (i.e. Cumbia, Mambo). In flamenco, the expression has come to us in a group of tangos recorded in 1946 by la Niña de los Peines, with the chorus "al guru guru" and lyrics telling of a married man's desire for a black woman and the jealousy this arouses in his wife. Camarón de la Isla, one of the greatest flamenco artists of all time, also used "guruguru" in his recordings from the 1970s. I especially liked the idea of using this 
word, which apart from being a first piece of evidence of African culture in Spain, follows this timeline into the twentieth century to speak to us of the indestructible memory of the African diaspora.

\section{Conclusion}

Today a new generation of Black Spaniards in search of models and recognition finds itself living in a country which, regardless of political differences between left and right, has forgotten its history of diversity and coexistence. Moreover, a significant part of the Spanish population does not identify with an exclusive and outdated Spanish nationalism still harking back to its colonial history and chauvinist pureza de sangre. Furthermore, closeness to and coexistence with African people who have arrived in the latest waves of migration create new questions concerning identity and borders. We are seeking new versions of the old historic narratives on the basis of which we can call into question the confining frontiers offered by nation states: new ways of belonging and new identities to adhere to.

The forgotten history of Black Spaniards can become a means of making visible and demanding rights which, by radically calling political frontiers into question, can cast doubt on the current status quo represented by the European Union's harsh migratory laws and the razor wire fences on our borders with Africa. In rejecting these unviable policies, we must make sure that this memory does not disappear or become banalized and pressed into the service of interests akin to those which, long ago, gave rise to injustice, violence, and silence.

\section{Works Cited}

Appadurai, Arjun. Fear of small number. Duke U P, 2006.

Archivo General de Indias, "La Compañía Gaditana de Negros." Sevilla.

Augé, Marc. Le temps en ruines. Editions Galilée, 2003.

Benhabib, Seyla. Critique, Norm and Utopia: A Study of the Foundations of Critical Theory. Columbia U P, 1986.

De Jesús, Teresa. Libro de la Vida. San Pablo, 2007.

Del Campo, Alberto \& Rafael Cáceres. Historia cultural del flamenco: El barbero y la guitarra. Almuzara Editorial, 2013.

Fra Molinero, Baltasar. La imagen de los negros en el teatro del Siglo de Oro. Siglo XXI Editores España, 1995.

García de León, Antonio. Fandango: El ritual del mundo jarocho a través de los siglos. Programa de Desarrollo Cultural del Sotavento, 2006.

Gilroy, Paul. The Black Atlantic: Modernity and Double Consciousness. Verso, 1993.

Machado y Álvarez, Antonio. Colección de Cantes Flamencos, recogidos y anotados por Demófilo. Imprenta El Porvenir, 1881.

Moreno, Isidoro. La antigua hermandad de los negros de sevilla: etnicidad, poder y sociedad en 600 años de historia. Editorial Universidad de Sevilla, 1982.

Nerin, Gustau. La Ultima Selva de Espana: Antropofagos, Misioneros y Guardias Civiles: Cronica de La Conquista de Los Fang de La Guinea Espanola, 1914-1930. Libros de La Catarata, 2010.

Romero, Pedro G. "El sol cuando es de noche. Apuntes para habilitar una poética y una política entre flamencos y modernos, sitio paradójico." La noche española: Flamenco, vanguardia y cultural popular 1865-1936. Museo Nacional Centro de Arte Reina Sofía, 2008, pp. 48-89. 
Rosales, Miguel Á. Gurumbé. Canciones de tu Memoria Negra. Intermedia Producciones, 2016. Ruíz Vergara, Fernando. Rocio. Tangana Films, 1980.

Trouillot, Michel-Rolph. Silencing the Past: Power and the production of History. Beacon, 1997. 